Journal of Social and Development Sciences

Vol. 4, No. 3, pp. 147-151, Mar 2013 (ISSN 2221-1152)

\title{
The Flexible Alternative Consumer Financing in Malaysia: Credit Cards
}

\author{
*Devinaga Rasiah, Md. Shukor Masuod \\ Multimedia University, Malacca Campus, Malaysia \\ *devinaga.rasiah@mmu.edu.my
}

\begin{abstract}
This study examines the changes occurring in the consumption behavior of the Malaysian consumers towards the use of credit cards as a source of consumer finance. Use of credit cards as payment had considerably multiplied in Malaysia ever since 1990s. Supported by the conceptual framework, five independent variables were employed. This was evaluated with respect to one dependent variable in this study. The dependent variable was the credit card. The questionnaire was tested using 160 questionnaires, using validity test, linear correlation, descriptive statistics and multiple regressions to test the results. The results indicated that there was a relationship between credit card debts, attitude, income, understanding/knowledge, potential impact of credit card utilization among bank customers. The study can be used by banks to be aware of the increased usage of credit cards which can give rise to increase in consumer finance in the future.
\end{abstract}

Keywords: debt, credit card, loan, banks, payment

\section{Introduction}

Credit cards, like Visa, MasterCard, Diners Club, American Express and others are short term lines of consumer finance, depending on the terms, which allowed an individual to consume an assured and an acceptable amount of money and returned at regular intervals by Norudin and Zull Nikli, (2005) and Akers, Golter, Lamm, \& Solt, (2005). According to Bank Negara Malaysia statistics illustrated that credit cards distribution had grown 278 percent in the last eight years. From 2.8 million in the year 2000 to 10.6 million in 2008, indicating that credit cards as an appropriate electronic payment device. In the same way, the unsettled amounts per credit card holder escalate by $15.1 \%$ to RM9, 516 as at end-2010 as the quantity of credit cardholders with revolving balances were $47.9 \%$ of total credit card holders. Bank Negara Malaysia, added that the non-performing loans (NPLs) ratio for credit cards issued by banks and non-banks stayed put at $1.7 \%$. Unresolved credit card balances amplified by $15.2 \%$ to RM30.8 billion as at end-2010 with a balance of $5.3 \%$ of household debt. Presently there are a hefty proportion of qualified Malaysians who did not hold credit cards. This research will help the Commercial bankers to identify factors that affected credit cards usage and to articulate strategies as to how to get rid of the bad factors that affected the use of credit cards. Based on the profile of debtors who had sought the assistance of "Counseling Agency and Credit Management" in problems with debt. This included credit card arrears of 60 percent of which credit card defaulters were lesser between the 40 to 65 percent, consumers who receive less than RM36, 000-00 per annum. Davies and Lea (1995) indicated that educating credit cardholders was important to teach customers good spending habits which cannot therefore be overlooked. Brito and Hartley (1995) had indicated that nowadays it was clearly significant that credit cards allowed the users to be flexible and increased their ability to spend. Aizcorbe, et al. (2003) indicated that installment plans provided more time and leeway for paying back the amounts used at a later date. In a similar study carried out by another researcher showed that there were no barriers for the users to spend in any currency given that retail stores were merely concerned if the cards were VISA or Master cards which are serviceable internationally. Bernthal et al (2005) mentioned that the factors which determined the credit card adoption had led to the development of marketing strategies of commercial banks, because the competition in the credit card industry were currently not just coming from banks but also from nonbanks, such as departmental store credit cards, with VISA or MasterCard, which allowed cardholders to apply cards worldwide as well. 
Background of the Study: Banks had introduced the usage of credit cards as a technique of strategizing the marketing efforts to attract more customers. Devlin, Worthington, and Gerrard (2007) had indicated that competition among banks and credit card issuing companies had become very high nowadays. Credit card debt had increased steadily because of the high growth rate of credit cards. Since the late 1990s, the government had become increasingly concerned about the rising usage of credit cards among commercial bank customers. Ausubel (1997) mentioned that the major credit card companies had targeted young working adults who had just joined the work force and who were typically less experienced at managing their money and creating a budget as to how to spend their finances. Goyal (2004), had indicated that credit card debt had negatively affected their financial performance as they were likely to manage their financial cash flow better since they were working individuals. Bank Negara Malaysia's (2001) in their annual report mentioned that credit cards distribution was favorable in Malaysia; the average growth rate $12.5 \%$ over 9 years was issued to customers whereas the usage multiplied with a 23\% growth rate from year 1992 to 2000, Wertenbroch (2003), mentioned that there was gave consumers a degree of financial freedom that other payments methods can't offer.

Research Objectives: To identify the factors contributing to high growth rate of credit cards as an alternative to consumer financing in 2 states such as in Negeri Sembilan and Malacca. To examine the independent variables that impacted the credit card usage. The significance of this research would be supportive to determine the credit card treatment as an alternative to short term credit had increased in commercial banks because competition in credit cards are also coming from non- banks such as departmental stores credit cards with VISA or Master cards, this allowed cardholders to apply cards world wide as well.

\section{Literature Review}

In Malaysia, banking innovations and changes had prepared the market further aggressive and attractive. Presently, there is a necessity to examine the customer behavior towards the use of plastic cards, especially through the application of credit cards. As judged against the remainder of the market, credit cards had not existed as a dynamic source for the Malaysia economy but nowadays things are changing, since the introduction of many financial services which allowed individuals to do their purchases without cash, many customers had decided to switch from the use of paper money to plastic money. Cargill and Wendel (1996) indicated that bank customers' treatment of credit cards had lately obtained greater than before pronouncement throughout the media as indicated by Hayhoe, Leach, \& Turner (1999), and Hayhoe, Leach, Turner, Bruin, \& Lawrence (2000). Henry concluded that in addition to credit problems many customers did not have a written budget, but the younger group of customers had a financial plan. Daljit (1999), in one of his studies had indicated that MasterCard, Malaysia registered the maximum index of consumer confidence. It expanded to a good intensity of $67.6 \%$ to $89.3 \%$ from year 1998 to 1999 (Daljit, 1999). The boosted support was owing to the progressive development in the country's fiscal policies. Chu (2008) highlighted that credit card providers had come up with widespread marketing strategies to contest rigorously. Devlin, Worthington and Gerrard (2007) had indicated that financial and credit card establishments only endorse co-branding to promote their product. The stated results indicated that there was a momentous association between credit card debt and credit card usage. For this reason, the hypotheses statement indicated that credit card debt affected credit card usage was accepted. Most of the respondents did not own a credit card because they were afraid that they might get into a credit card debt, if they didn't manage their credit card transactions properly. There was correlation between potential impact and credit card consumption in this research. Lehnert and Dean (2001) indicated that high interest rates, high credit limits and annual fees charged applied for a credit card could lead to a credit card debt and as a result affected or changed the life of an individual. Lopes, (2003), also mentioned that respondents were not willing to face those potential impacts when they thought of applying for a credit card. In July 2008 a tiered pricing structure for credit cards was introduced. The objectives were to promote management of finance amongst credit card users. The Dependent variable in this study was Credit cards usage and the Independent variables were attitude of card holder, understanding of credit card usage, education, consumer income, Impact of usage of credit card and consumer credit card debts 


\section{Data Analysis and Findings}

This study performed on credit card users were from two states in Malaysia such as Negeri Sembilan and Melaka. About 200 questionnaires were distributed to the targeted respondents and 160 usable data were collected. The data employed was poised from a survey conducted on active credit cardholders 2010 to February 2012. Active credit cardholders (active accounts) require at least RM50 purchases per month. All credit card providers require a least amount of payment towards their credit card bill. Consequently, credit cardholders using less than RM50 would be grouped as inactive credit cardholders and were ruled out from the study. The credit cardholders were acquired both from beginning to end face-to-face interviews or selfadministered questionnaires. Frequency analysis was used to analyze the demographic variables which include age, gender. The conclusion implied that males were additional careful with their expenditures using credit than females, which disagrees from the findings of Yieh (1996), and Yilmazer \& DeVaney (2006) and Lyons (2003) indicating ethnicity, education and income level similar studies conducted by Lee and Kwon, (2002). It was indicated that the highest percentage of respondents for this survey were customer between the age group of (40-55) which was $62.5 \%$ percentage. The second highest age group was (25-39) with a percentage of $36.3 \%$ and a total of 58 respondents. This was followed by (18-24) age group with a lowest percentage of $(0.9 \%)$. In the other hand, when looking at the ethnicity $50 \%$ of respondents were Chinese, the second highest percentage of respondents were Malays with a percentage of $30 \%$. The third highest percentages of respondents were Indians with $15 \%$. In terms of the level of education, the highest respondents of this survey is $80 \%$ are degree holders, $2.5 \%$ of the respondents had at least a diploma and some had successfully completed a particular course or study. A credit cardholder with a university degree is 1.5 times more probable to pay his monthly bill in full than a credit cardholder who did not receive a tertiary education. Similar, studies show that Zhu and Meeks (1994) and Choi and DeVaney (1995) in their studies showed negative relationship between education and credit use. T 5.6\% was skilled workers with their own business and $1.9 \%$ are doing some training or working as professional technicians etc. Similar studies had been conducted by a researcher called d' Astous and Miquelon (1991) had indicated that education was an important variable in the prediction of using credit cards.

Table 1: shows Total loans and credit card loans

\begin{tabular}{|c|c|c|c|c|c|c|c|c|c|c|}
\hline $\begin{array}{l}\text { RM } \\
\text { mn } \\
\end{array}$ & 2006-Dec & 2007-Dec & 2008-Dec & 2009-Mac & Jun2009 & Sep2009 & Dec2009 & Mar2010 & Jun2010 & Sep2010 \\
\hline $\begin{array}{l}\text { Total } \\
\text { loans }\end{array}$ & $593,013.97$ & $644,237.10$ & $726,545.73$ & $733,873.51$ & $742,770.86$ & $763,749.62$ & $783,507.33$ & $805,690.37$ & $834,935.48$ & $854,181.23$ \\
\hline $\begin{array}{l}\text { Credit } \\
\text { cards }\end{array}$ & $19,912.03$ & $22,769.92$ & $24,948.56$ & $24,362.76$ & $24,850.13$ & $25,385.78$ & $26,389.92$ & $26,557.97$ & $27,683.69$ & $28,672.53$ \\
\hline
\end{tabular}

Source: CEIC data base Malaysia (2010)

A figure of $57.5 \%$ respondents had an income level of RM1000 to RM5000, followed by $16.3 \%$ respondents with an income level of M5001-RM10, 000. As for the income level in the survey which indicated 17.5\% of respondents had an income level of RM10, 001 to RM15, 000. Next, there was an amount of $9.1 \%$ respondents for the income level of RM15001 to RM20, 000. As for the income levels above RM20, 000 and above showed a total of $0.6 \%$ respondents only. These findings appear to disagree with the results by Chien and DeVaney (2001), and Castronova \& Hagstrom (2004). Conceivably, consumers who took home a higher salary were more willing to keep their credit card account up to-date in contrast to those being paid a lesser salary. A total of $83 \%$ of the customers in this study did not own a single credit card. This was because the use of a credit card was not that common or popular in Malaysia yet compared to other countries around the world. From all the respondents $5 \%$ of them own one credit card, $6 \%$ of them own two credit cards and $6 \%$ of them own at least two credit cards. The study indicated that the Cronbach's Alpha reliability for credit card debts was 0.719. For that reason, the reliability analysis for credit card debts in this research was significant and reliable. To put it briefly, all of the Cronbach Alpha values were significant for all the variables as the values were more than 0.60 . The mean value for credit card debts was conducted using a total of 6 independent variables. The 6 independent variables had means ranging from 2.70 which was the lowest to 3.85 which was the highest. Variables number 6 "credit card debts are encouraged by the income earned monthly" had the highest mean of 3.75. This implied that most number of respondents believed that credit card debts are 
encouraged by the income they earned monthly. The lowest mean was 2.75 for variables "Credit card holders were impulsive spenders." It showed that fewer respondents agreed with variables number 4 . The highest mean was 3.80 for variables "potential impact of credit card which affected the usage of credit cards". This implied that most respondents did not own a credit card because of potential impact on them when they used a credit card. The lowest mean was 3.60 "attitudes towards the usage of credit cards".

Hayhoe, Leach, Turner, Bruin and Lawrence (2000) had indicated that the attitude towards the use of credit cards affected the usage of credit cards among bank customers. Shefrin (1988) had specified that the correlation coefficient analysis confirmed that there was a positive relationship between attitude toward the use of credit card and credit card usage with a significant value of $0.002(\mathrm{p}<0.05)$. Therefore it supported the hypotheses statement that attitude affected credit card usage. There was a positive correlation between understanding credit card usage with a significant value of $0.000(\mathrm{p}<0.01)$. It supported the hypothesis testing of the statement as to why it was important to know how to manage credit card usage. In a study by Norvilitis. et al. (2006) had indicated that the respondents agreed that in order for a bank customer to use credit card they should have the knowledge about credit card usage. The results indicated that recent researches such as Sulaiti, Ahmed, \& Beldona (2006) had found an affirmative association between earning a lesser income monthly and the number of credit cards consumed. Kaynak and Harcar (2001) mentioned that the raise in salary inflated positively to credit cards used. Following this highly educated people were more interested in new technologies than less educated people. Their incomes were also higher than the less educated people. Noor Ramayah et al. (2002) indicated that there was a significant positive relationship between the income level of a person and his/her ownership of the credit card.

\section{Conclusion}

Among the respondents $83 \%$ of the respondents had no credit card. This was because the consumption of credit card facility in Malaysia had been initiated in 1970 and more people started become accustomed to the use of credit cards only in the early 2000s when compared to some of the developed countries such as the United States having had this facility for many decades since 1985. The use of credit card and its facility had sustained it's grow despite a $21 \%$ reduction in the number of credit cards in circulation in 2010 . This could be mainly due to the enforcement by the Government service tax since Jan 1, 2010. Presented in the Bank Negara Malaysia's January 2011 reports, outstanding credit card debt stood at RM30.4bn and signified 3.4\% loan or $6.1 \%$ of household debt. In conclusion, the expected economy being slower this year, consumers in Malaysia have got to juggle around to manage their credit cards spending and payment of debts.

\section{References}

Akers, D., Golter, J., Lamm, B. \& Solt, M. (2005). Overview of recent developments. The credit card industry, 17(3).

Ana, M., Kennickell, A. B. \& Moore, K. B. (2003). Recent Changes in U.S. Family Finances: Evidence from the 1998 and 2001 Survey of Consumer Finances. Federal Reserve Bulletin, January 2003, 1-32.

Ausubel, L. M. (1997). Credit card drfault, credit card profit and bankraptcy. american bankraptcy law journal, 2, 249-270.

Astous, D. \& Miguelon, D. (1991). Helping consumers choose a credit card. The journal of consumer Affairs, 25 (2), 278.

Aizcorbe, A. M., Kennickell, A. B. \& Moore, K. B. (2003). Recent changes in U.S. family finances: evidence from the 1998 and 2001 Survey of Consumer Finances. Federal Reserve Bulletin, 89, 1-32

Bank Negara Malaysia. (2001). Financial Stability and Payment Systems Report, Kuala Lumpur, Malaysia

Bank Negara Malaysia. (2007). Financial Stability and Payment Systems Report, Kuala Lumpur, Malaysia

Bank Negara Malaysia. (2011). Financial Stability and Payment Systems Report, Kuala Lumpur, Malaysia

Bernthal, M. J., Crockett, D. \& Rose, R. L. (2005). Credit Cards as Lifestyle Facilitators. Journal of consumer research, 32(1), 130.

Brito, D. L. \& Hartley, P. R. (1995). Consumer rationality and credit card. The journal of political economy, 2, 400 . 
Cargill, T .F \& Wendel, J. (1996). Banks Credit cards: Consumer irrationality versus market forces. The Journal of Consumers Affairs, 30(2), 373.

Castronova, E. \& Hagstrom, P. (2004). The demand for credit cards: evidence from the survey of consumer finance. Economic Inquiry, 42, 304-318.

Chien, Y. \& DeVaney, S. (2001). The effects of credit attitude and socioeconomic factors on credit card and installment debt. The Journal of Consumer Affairs, 35, 162-179.

Choi, H. N. \& Devaney, S. (1995). Factors associated with the use of bank and retail credit cards. proceedings of the society for consumer psychology. american psychology association, 2, 152-159.

Chu, K. (2008). Credit cards go after bank customers; Banks increase efforts to forge relationships with attractive demographic. USA today, 6B.May.

Daljit, D. (1999). VISA expects overall growth of between 5 percent and 10 percent. The Star.

Davies, E. \& Lea, S. G. (1995). Customers Attitude to Customer Debts. Journal of economic psychology, 1, 663679.

Devlin, J. F., Worthington, S. \& Gerrard, P. (2007). An analysis of main and subsidiary credit card holding and spending. The International Journal of bank Marketing, 2592, 89.

Goyal, A. (2004). Role of supplementary services in the Purchase of credit card services in India. Asia Pacific Journal of marketing and logistics, 16(4), 36.

Hayhoe, C., Leach, L. \& Turner, P. (1999). Discriminating the number of credit cards held by college students using credit and money attitudes. Journal of Economic Psychology, 20(2), 643-656.

Hayhoe, C., Leach, L., Turner, P., Bruin, M. \& Lawrence, F. (2000). Differences in spending habits and credit card use by bank customers. 113-133. The Journal of Consumer Affairs, Article first published online: 3 March 2005

Kaynak, E. \& Harcar, T. (2001). Consumer's attitudes and intentions towards credit card usage in an advanced developing country. Journal of Financial Services Marketing, 6(1), 24-39.

Lee, J. \& Kwon, K. (2002). Consumers' use of credit cards: Store credit card usage as an alternative payment and financing medium. The Journal of Consumer Affairs, 3, 239.

Lehnert, A. \& Dean, M. M. (2001). Consumption, Debt, and Portfolio Choice: Testing the Effect of Bankruptcy Law Mimeo.

Lopes, P. (2003). Credit Card Debt and Default over the Life Cycle", Working Paper, Financial Markets Group, London School of Economics.

Lyons, A. (2003). How credit access has changed over time for U.S. households. Journal of Consumer Affairs, 37, 231-255.

Noor Ramayah, N., Nasurdin Aizzat, M. \& ChooLim, H. (2002). Cardholders' attitude and bank credit card usage in Malaysia. an exploratory study, 7(1).

Norudin, M. \& Zull Nikli. (2005). Islamic Credit Card Usage in Working Middle-Class. Paper presented at The Malaysian Finance Association 7th Annual Conference. UiTM Terengganu and MFA, Kuala Terengganu

Norvilitis, J. M., Merwin, M. M., Osberg, T. M., Roehling, P. V., Young, P. \& Kamas, M. M. (2006). Personality factors, money attitudes, financial knowledge and credit card debt in college students. Journal of Applied Social Psychology, 36, 1395-1413.

Shefrin, H. (1988). The Behavioral life cycle hypothesis. Economic Inquiry, 2, 604-643.

Sulaiti, K. A., Ahmed, Z. U. \& Beldona, S. (2006). Arab Consumers' Behavior towards Credit Card Usage: A Comparative Analysis of Consumers across Middle Eastern Countries. Journal of Transnational Management, 12(1), 65.

Wertenbroch, K. (2003). Self-Rationing: Self-Control in Consumer Choice, in George Loewenstein, Roy Baumeister, and Daniel Read (Eds), Time and Decision: Economic.

Yieh, K. (1996). Who has a negative attitude towards installment debt in U.S? Consumer Interests Annual, 42, $135-140$.

Yilmazer, T. \& DeVaney, S. (2006). Household debt over the life cycle. Financial Services Review, 14, 385-304.

Zhu, L. \& Meeks, v (1994). Effects of low income families' ability and willingness to use consumer credit on subsequent outstanding credit balances. Journal of Consumer Affairs, 28, 403-422. 